\title{
Personally significant topic and a new typology of lessons in contemporary education
}

\author{
Vladimir V. Shogan ${ }^{1 *}$, Ekaterina $V$. Storozhakova ${ }^{1}$, Zhanna $S$. Metelkina $^{2}$, and Valentina A. \\ Ageeva $^{3}$ \\ ${ }^{1}$ Institute of History and International Relations of SFU, Department of Special Historical Disciplines \\ and Documentation, Rostov-on-Don, Russia \\ ${ }^{2}$ Institute of History and International Relations of SFU, Department of Russian History, \\ Rostov-on-Don, Russia \\ ${ }^{3}$ Taganrog Institute named after A.P. Chekhov, Faculty of History and Philology, Taganrog, Russia
}

\begin{abstract}
The prerequisites for the present article have been abstracting and moving away from the knowledge-based learning paradigm, creating innovative forms of lessons that carry elements of metadisciplinarity, and the transformation of a set of lessons combined into personally-significant topics into a complete technological complex. A personally significant topic, in its productivity, carries a change in the pupil's attitude to the world. It is understood as a structural unit of this change. The article offers an invariant structure that includes image, analysis, meaning, action, and reflection, which corresponds to new types of lessons, namely, image lesson, thinking lesson, mood lesson, independent action lesson, as well as actualization and reflection lesson. In general, the proposed set of lessons represents a new technology, whose purpose is to address the subject content to the emotional sphere of pupils, to perceive the value-semantic basis of the topic as conditions for future digital analysis. The methods used included observing the work of the experimental and control classes, test tasks, using the valuable words of the text, and color analysis of emotional expressions. The results of this work have been aimed at improving the quality of pupils' knowledge, developing ways of thinking, appealing to the value-semantic context of the humanities-based subjects, and embodying the acquired competencies in action situations as the basis for adaptation and socialization of the education subject.
\end{abstract}

Keywords: personally significant topic, image lesson, mood lesson, independent action lesson, actualization and reflection lesson.

\section{Introduction}

The relevance of the article lies in the fact that it makes a significant step away from the knowledge-based approach. The knowledge-based approach is always strictly objective and is aimed at formative systematization, which in turn deprives it of metacompetent capabilities. Alienated knowledge loses its creative nature, becomes static, and turns into information independent of the individual's consciousness [1]. In this sense, a personally

* Corresponding author: shogan.vladimir@yandex.ru 
significant topic aims at creating conditions for qualitative change in the world attitude of the subject of education, that is, at educating intellectual, moral, and aesthetic feelings. "The mentality that defines human life from birth to death..." [2: 4]. While perceiving human existence not as a train of thoughts, but according to S. Frank, as a stream of total feeling, then "What is directly given to us in experience is reality, which we create as something primary, as the last depth and absolute, giving the last highest joy of perfect satisfaction and delight in terms of subjective experiences - there are feelings that exactly are being" [3:470]. It is possible to speak with intuitive confidence, which is based on the experience of working with schoolchildren, about the modi of being, as the real states of the subject of education. This refers to the five deep states or images of being identified in the experimental work: the modus of integrity, the modus of thinking, the modus of reflection, the modus of creativity, and the modus of embodiment.

These deep states-images are not set to the subject but are given. The task of contemporary pedagogy is to create conditions to awaken and actualize these modi. A contemporary person, a pupil as a subject of education, being an individual, is inclined to see the world holistically in any of its beginnings. Boehme, pointing to the stability of human nature, wrote: "Where there is nothing, there is nothing; all things must have their cause or root, otherwise nothing will grow" [4: 35].

\section{Methods}

Employing the method of theoretical analysis of philosophical, pedagogical, and psychological research, the following modi of being were identified: the modus of thinking, the modus of reflection, the modus of creation, and the modus of embodiment. "It is the longing for unitotality that lies at the heart of our suffering about the vanity and nonsense of life, and since we rise in consciousness above all this vanity, this mental ascent represents some preliminary way out of the whole vicious circle in which we languish" [5: 60].

\section{Results}

The identified modi have allowed defining a new invariant structure of training and upbringing, where each training event and upbringing event are represented by components, such as image, analysis, meaning, action, and reflection, which obviously corresponds to the modi of being. Each event of training or education is a personally significant topic that develops in the context of this structure. The experimental work has revealed that when a certain set of personally significant topics is completed, there is a need for another stage, which in this study is called adaptation. It is a stage of immersion into information, which is also represented by an invariant structure. "The requirements of the possibility of a simple sign are the requirements of a certain meaning" [6:21]. This concerns the components of digital content that in the experimental work have received the names of the matrix-based lesson, the lesson of combinatorics, the exam lesson, and the computer game.

The image lesson is the first lesson of a personally significant topic, which presents in a meaningful context the symbol of the topic, key concepts of the topic, the key typological person of the topic, and key creative assignment of the topic. The lesson develops in five fragmentary complexes. The first fragmentary complex is a motivational-symbolic one, the second is a preemptive rational representation (conceptual), the third is a complex of typological personification, and the fourth is a complex of creative task, i.e. reflection.

The thinking lesson has a different structure. Here, the image is an intellectual intriguing beginning. The lesson then turns into a recollection component, which ends with partial uncovering of the intriguing mystery of the lesson. Further, mastering new knowledge occurs 
according to a special technique, which ends with uncovering the remaining part of the intrigue. The lesson then orients at efficient consolidation, and finally, ends with full uncovering of the intrigue. Here it is important to ensure that the uncovering of the intrigue should be more interesting than the beginning of the lesson. In general, different types of thinking lessons are assumed, such as abstract thinking lessons, plot thinking lessons, artistic thinking lessons, and extensional thinking lessons.

The lesson of independent action takes place in the form of a microgroup seminar. According to the authors' idea, all seminars, as lessons of independent action, are divided into linear ones, and have a reproductive-generalizing character, namely, unilinear - three microgroups, bilinear - six microgroups, and trilinear - nine microgroups. There is also a certain set of multistage seminars based on the increasing complexity of the problem situations and their resolution.

"The existence of the future is the experience of the integrity of life and its immortality" [7: 56].

The mood lesson is where the meanings of history, literature, geography, and social studies are uncovered for perception. This block is based on artistic means (prose, poetry, music, painting, theater), which form the basis for deep dialogues between persons of humanitarian subjects and pupils. During the lesson, the pupils' conscious concentration on a single object is lost in constantly decreasing cycles, i.e., the time during which the maximum concentration of attention is possible, decreases [8]. Sartre writes: "We have grasped a being that escapes knowledge and which serves its basis, a thought that is not given at all as a representation or meaning of ready-made expressions, but which is grasped directly as it is, this method of grasping is not a phenomenon of knowledge, but the very structure of being" [9: 31].

\section{Discussion}

Thus, from the lesson of the total image, through personally significant topics, in which the understanding of key concepts and typological persons is born from the deep lives of pupils, one turns to the mood block, in which the effect of separating the rational from the sensual arises. Connecting this alternative state is possible only in an independent creative action, which is the defense of projects.

Further, when lessons and extracurricular work have interpermeated in the synthesis of projects, the extracurricular adaptation block starts acting. Such classes have a sense and practical effectiveness when high school students get into the conditions of solving the tasks of the unified state exam, or basic state examination, which are as close to reality as possible. The learning process is implemented taking into account characteristic features, such as the optimal content and dosage of training tasks, the pupil's performance [10]. Here are presented the main plot lines of the content of the future exam, based on the materials of the Federal State Educational Standard. When extracting the meaning of information, the individual's experience, the work of his imagination, creativity, and intuition are important. The relationships that appear in the course of information processing with personal experience give rise to personal meanings [11]. After this kind of analytical work, pupils enter the semantic stage of the information block - they participate in the test exam, which is naturally shortened in time but has all the features appropriate for the exam. The value of understanding lies in its close connection with the purpose of a person in life and their awareness of their place in the world, with the choice of ways and models of behavior in society [12]. 


\section{Conclusion}

Thus, in the course of conducted experimental work, it is proved that the use of new types of lessons makes it possible to increase the interest of pupils in the subjects studied. At the same time, as the testing has shown, the high school students who have passed in their training the stage of mental perception of subjects in personally significant topics, and the stage of immersion into information starting from the matrix to the game, are significantly higher in terms of the percentage of acquired knowledge than those who were trained according to the traditional paradigm. The e-learning system in a virtual learning environment effectively forms the cognitive skills of pupils [11]. The use of ICT has impact on all participants of the educational process within the framework of information and educational environment, and thus becomes an effective mechanism in the development of the e-learning environment, which is confirmed by the works of I. Golitsyna [13] and others. Research by I. Semradova, S. Hubackova [14], and A. Sari [15] confirm that in the virtual information environment of e-learning, the pupils' communication skills do not deteriorate, but only develop, improving their motivation and success.

\section{References}

1. N.A. Schechtman, Volga Pedagogical Bulletin, 2, 154-156 (2015)

2. V.V. Shogan, Etyudy o glubinnoy didaktike [Sketches on deep didactics] (Rostov-onDon, 2016)

3. S. Frank, S nami Bog [God With Us] (AST, Moscow, 2010)

4. J. Boehme, Avrora, ili utrennyaya zarya v voskhozhdenii [Aurora, or morning dawn in ascent] (Vita Nova, Saint-Petersburg, 2015)

5. N. Cusanus. Compendium. Okhota za mudrostyu. O vershine sozertsaniya [Compendium. On the hunt for wisdom. On the summit of contemplation] (Academic Project, Moscow, 2015)

6. L. Wittgenstein, Zametki po filosofii psihologii [Remarks on the philosophy of psychology] (Dom intellektualnoi knigi, Moscow, 2001)

7. E.V. Storozhakova, Glubinnyy dialog v vysshem pedagogicheskom obrazovanii [Deep dialogue in higher pedagogical education] (Vuzovskaya kniga, Moscow, 2014)

8. N.A. Bradbury, Advances in Physiology Education, 40(4), 509-5013 (2016). https://doi.org/10.1152/advan.00109.2016.

9. J.P. Sartre, Bytiye i nichto: Opyt fenomenologicheskoy ontologii [Being and Nothingness: An essay on phenomenological ontology] (Respublika, Moscow, 2004)

10. T.Sh. Shikhnabieva, The Science of Person: Humanitarian Researches, 3, 98-104 (2018)

11. N.V. Demshina, L.A. Mosunova, Scientific and Technical Information Processing, 46, 110-116 (2019). https://doi.org/10.3103/S0147688219020096

12. L.S. Fuchs, J.K. Gilbert, D. Fuchs, P.M. Seethaler, B.N. Martin, Scientific Students of Reading, 22(2), 152-166 (2018). https://doi.org/10.1080/10888438.2017.1398259

13. I. Golitsyna, Procedia - Social and Behavioral Sciences, 237, 939-944 (2017). https://doi.org/10.1016/j.sbspro.2017.02.132

14. I. Semradova, S. Hubackova, Procedia - Social and Behavioral Sciences, 89, 450-453 (2013). https://doi.org/10.1016/j.sbspro.2013.08.876 
15. A. Sari, Procedia - Social and Behavioral Sciences, 116, 4939-4945 (2014). https://doi.org/10.1016/j.sbspro.2014.01.1053 